\title{
Relation between Angle Class II malocclusion and deleterious oral habits
}

José Tarcísio Lima Ferreira', Maria do Rosário Ferreira Lima², Luciana Zappeloni Pizzolato³

Introduction: Oral habits may interfere on the growth and development of the stomatognathic system and orofacial myofunctional conditions, producing changes in the position of teeth in their dental arches. Objective: The purpose of this study was to verify the presence of deleterious oral habits in individuals with malocclusion and see if there is a predominance of Class II malocclusion in these individuals. Methods: The records of 140 patients treated at the Clinic of Preventive Orthodontics FORP-USP who had already completed treatment were randomly selected and analyzed. Their ages ranged from 6 to 10 years and 11 months. Associations were made between the presence or absence of deleterious oral habits, type and number of habits found in each individual and the type of malocclusion according to Angle classification. The statistical analysis used was the Chi-square test with a significance level of $5 \%$. History of deleterious oral habits was found in $67.1 \%$ of individuals. Results: The Class I malocclusion was most frequent (82.9\%), followed by Class II malocclusion (12.1\%) and Class III (5\%). Conclusion: There was a predominance of Class II malocclusion in individuals with a history of deleterious oral habits.

Keywords: Angle Class II Malocclusion. Habits. Finger sucking.

Introdução: hábitos bucais podem interferir no crescimento e desenvolvimento do sistema estomatognático e nas condições miofuncionais bucofaciais, acarretando alterações no posicionamento dos dentes nas respectivas arcadas dentárias. Objetivo: o objetivo dessa pesquisa foi verificar a presença de hábitos bucais deletérios em indivíduos portadores de má oclusão e observar se existe predominância de má oclusão Classe II de Angle nesses indivíduos. Métodos: foram selecionadas, aleatoriamente, e analisadas 140 fichas de pacientes atendidos na Clínica de Ortodontia Preventiva da FORP-USP, que já haviam recebido alta no tratamento. A faixa etária variou dos 6 anos a 10 anos e 11 meses. Foram realizadas associações entre presença ou ausência de hábitos bucais deletérios, tipo e número de hábitos encontrados em cada indivíduo e o tipo de má oclusão, segundo a classificação de Angle. A análise estatística utilizada foi o teste qui-quadrado para independência, com nível de significância a 5\%. História de hábitos bucais deletérios foi encontrada em $67,1 \%$ dos indivíduos. Resultados: a má oclusão Classe I foi a mais encontrada (82,9\%), seguida das más oclusões de Classe II (12,1\%) e Classe III (5\%). Conclusão: houve predomínio de má oclusão Classe II de Angle nos indivíduos com história de hábitos bucais deletérios.

Palavras-chave: Má oclusão de Angle Classe II. Hábitos. Sucção de dedo.

${ }^{1} \mathrm{PhD}$ in Materials Engineering, UFRJ. Professor.

${ }^{2}$ Professor of Speech Therapy, Center for Higher Education - Juiz de Fora.

${ }^{3}$ Speech therapist.

Submitted: May 25, 2009 - Revised and accepted: April 12, 2010

\begin{abstract}
How to cite this article: Ferreira JTL, Lima MRF, Pizzolato LZ. Relation between Angle Class II malocclusion and deleterious oral habits. Dental Press J Orthod. 2012 Nov-Dec;17(6):111-7.

» The author reports no commercial, proprietary or financial interest in the products or companies described in this article.
\end{abstract}

Contact address: José Tarcísio Lima Ferreira

Av. do Café, S/N - Bairro Monte Alegre - Ribeirão Preto/SP - Brazil CEP: 14040-904 


\section{INTRODUCTION}

The harmony and balance of the muscular modeling action on the dental arches can favor an adequate occlusion, as well as any change in the functional mechanism can determine deviations and consequent bone deformations. ${ }^{29}$

Changes in dental occlusion that may cause disorders in the stomatognathic system are grouped under the term malocclusion. Angle ${ }^{2}$ defined it and classified the changes that occur in occlusion in three classes: Class I, Class II and Class III.

In clinical practice, a considerable number of patients with malocclusion, referred by orthodontists to speech assessment, have oral habits. These may affect the shape and/or function of the stomatognathic system as supporting or adjuvant factors for functional alterations.

The literature reports changes in this system in children whose oral habits persisted after four years of age, especially those with finger sucking, pacifier, lip sucking or bottle feeding. It is common to find mandibular retrognathia, maxillary prognathism, open bite, hypo- or hypertonic upper and lower lip muscles, atresia of the palate, infantile swallowing; maxillary deficiency and mouth breathing. Besides these, it is also associated with changes in tooth position, characterizing problems in occlusion.

Considering that occlusal and oral motor system changes can be seen in people who have oral habits, the purpose of this study was to verify the presence of deleterious oral habits in patients with malocclusion and assess whether there is a predominance of Class II malocclusion in these patients or not.

\section{LITERATURE REVIEW}

Habit is the custom or practice acquired by frequent repetition of the same act, it is at first a conscious act and later it become unconscious. ${ }^{1}$ The oral habits considered harmful are finger sucking, the pacifier and improper posture and/or lip sucking, mouth breathing and atypical lingual pressure, promoting the imbalance of the neuromuscular system, causing changes in occlusion and facial pattern. ${ }^{22}$ Although the suction behavior is normal in infants and children, prolonged dura- tion may have implications on the development of orofacial structures and occlusion. ${ }^{14,20}$ Thus, changes in dental occlusion can be found in people who have harmful oral habits, , 5,6,7,19,26,30 especially if they appear in early childhood. ${ }^{19}$

Several authors agree that prolonged sucking habits are etiological factors of malocclusion ${ }^{4,11,30}$ due to the mechanical force exerted by the pacifier and the unbalanced muscular actions ruling on the jaws and teeth. ${ }^{20}$ The documented prevalence of malocclusion in children is high (49.7\%)..$^{27,28}$

Changes in the posture of lips and tongue may be the result of artificial feeding and acquired habits, exerting negative effects on the occlusion. They can also be caused by malocclusion, both dental and skeletal. ${ }^{9}$

During suction, excessive force is often shown by the cheeks against the posterior maxillary segments. Thus, overjet, anterior openbite and posterior crossbite are common to be found in these individuals. ${ }^{18}$ Larsson $^{13.14}$ showed that non-nutritive sucking habits were associated with certain types of malocclusion in the deciduous dentition including anterior open bite, increased overjet and canine and molar Class II relationship. Antonini et $\mathrm{al}^{3}$ observed that the sucking habits appear to be related to the skeletal maxillary protrusion and Class II skeletal pattern, due to maxillary protrusion that is established early in the primary dentition and remains unchanged in the transition to the mixed dentition.

The prevalence of habits is very variable and depends on many factors, including cultural. ${ }^{16,21}$ In Western countries up to $95 \%$ of children may have some habit, whereas in Africa and Asia it is unusual and, for the Inuit (Eskimos), it is unknown. ${ }^{16}$

A study by Tomita et $\mathrm{al}^{28}$ aimed to determine the prevalence of malocclusion and its relation with environmental factors such as oral habits and speech problems in 2139 pre-school of the public education system and private school in the city of Bauru, SP. Children between ages 3 to 5 years, of both genders, were subjected to cross-sectional study in two stages: Examination of the occlusion and socio-economic questionnaire. To classify the occlusion, authors used the Angle classification, and observation of horizontal and vertical over- 
bite, spacing/crowding, anterior open bite, total crossbite, anterior and posterior crossbite, unilateral or bilateral crossbite.

The results showed that malocclusion occurred in $51.3 \%$ of boys and $56.9 \%$ of girls, being higher at the age of 3 years, decreasing over time. Pacifier sucking was the most important habit in relation to malocclusion, followed by finger sucking. Changes in speech did not influence the occlusal relation.

In order to analyze the frequency of occurrence of malocclusion in children aged 5-8 years old, with the habit of finger sucking or pacifier, Vieira and Pillon ${ }^{29}$ evaluated 155 children of both genders in São Paulo, Brazil. Among the assessed children, $80 \%$ had abnormal occlusion, and $63.2 \%$ had Angle Class II, $14.2 \%$ Class I and $2.6 \%$ Class III.

Based on the descriptions above, the present study aims to determine: a) the presence of deleterious oral habits in individuals with malocclusion b) if there is a predominance of Angle Class II malocclusion in patients with vicious oral habits.

\section{MATERIAL AND METHODS}

This study was approved by the Ethics in Research Committee involving Human Beings, School of Dentistry of Ribeirão Preto, University of Sao Paulo, FORP / USP (Of.CEP/23804/ FORP/090804).

From the inactive file at the University of São Paulo, Ribeirão Preto Campus, consisting of 1100 records of treated patients, 140 medical records were selected of individuals of both genders, with malocclusion, ages from 6 years to 10 years and 11 months treated at the Clinic of Preventive Orthodontics, School of Dentistry. The data collected from medical records were obtained by undergraduate students under the supervision of instructors in the discipline of Orthodontics.

The information extracted from the records were related to: The presence or absence of deleterious oral habits, type of habit (when present); number of habits found in each individual and type of malocclusion according to Angle classification. ${ }^{2}$ The habits were suction (finger and lip, pacifier and bottle), bite (nailbiting, bruxism, biting objects, pen/pencil, shirt collar and lips) and face support.
Associations between oral habits and Angle malocclusion were observed, primarily considering the amount of habits found in every individual, regardless of type. Then, the types of habits found were considered: sucking, biting, sucking and biting or bite and face support. The statistical analysis used was the Chi-square test with a significance level of $5 \%$.

\section{RESULTS}

The presence or absence of habits associated with the different evaluated age ranges can be seen in Table 1 and the different habits found in relation to age are shown in Table 2. Regarding the number of habits, most patients had only one habit (53), followed by those who did not show any usual type (46), two types of habits (29), three (10) and four types of habits (2) (Table 1). The habit most frequently found was suction, followed by biting, associated biting and sucking, biting and face support (Table 2).

The different kinds of biting and sucking habits in relation to age can be seen in Tables 3 and 4, respectively. Regarding sucking habits, 32 patients had pacifier sucking, 27 finger sucking, 18 baby bottle and 4 lip sucking (Table 3). Considering the biting habits, 30 had nailbiting, 22 habit of biting pen / pencil, 6 biting shirt collar, 5 biting lip, 3 patients had bruxism and 1 had the habit of biting objects (Table 4).

The type of Angle malocclusion related to the age of individuals can be seen in Table 5 where it is possible to verify that from the 140 files, most had Angle Class I malocclusion (116), being most children in the age group of 8 years, followed by 9 and 7 years respectively. The Class II malocclusion was identified in 17 files, being most frequent between the ages of 8 and 9 years. The Class III malocclusion was found in 7 records, being mostly found in the age of 7 years.

The presence or absence of habits related with the malocclusion type, according to Angle classification are listed in Table 6. Among the patients with habits (94), 75 of them were Class I, 14 Class II and 5 Class III. The Chi-square statistical test was applied and did not allow to discard the possibility that individuals with oral habits presented predominance of Class II malocclusion, compared to those with no habits (Table 6). 
Table 1 - Presence or absence of habits in relation to age of the individuals.

\begin{tabular}{cccccccc}
$\begin{array}{c}\text { Number of } \\
\text { existing habits }\end{array}$ & $\begin{array}{c}\mathbf{6} \text { years } \\
\text { old }\end{array}$ & $\begin{array}{c}\mathbf{7} \text { years } \\
\text { old }\end{array}$ & $\begin{array}{c}\mathbf{8} \text { years } \\
\text { old }\end{array}$ & $\begin{array}{c}\mathbf{9} \text { years } \\
\text { old }\end{array}$ & $\begin{array}{c}\mathbf{1 0} \text { years } \\
\text { old }\end{array}$ & $\mathbf{n}$ & $\mathbf{\%}$ \\
\hline 1 habit & 3 & 14 & 22 & 11 & 3 & 53 & 37.9 \\
2 habits & 2 & 6 & 9 & 9 & 3 & 29 & 20.7 \\
3 habits & -- & 2 & 5 & 2 & 1 & 10 & 7.1 \\
4 habits & -- & -- & -- & 2 & -- & 2 & 1.4 \\
Absence of habits & 8 & 11 & 11 & 13 & 3 & 46 & 32.9 \\
Total & 13 & 33 & 47 & 37 & 10 & 140 & 100 \\
\hline
\end{tabular}

Table 2 - Types of habits found.

\begin{tabular}{ccc}
\hline Habits & n & $\%$ \\
\hline Suction & 38 & 40.42 \\
Biting & 31 & 32.98 \\
Suction and Biting & 23 & 24.47 \\
Biting and Face support & 2 & 2.13 \\
Total & 94 & 100 \\
\hline
\end{tabular}

Table 3 - Relation between the different sucking habits and age.

\begin{tabular}{|c|c|c|c|c|c|c|}
\hline \multirow{2}{*}{ Biting habits } & \multicolumn{5}{|c|}{ AGE } & \multirow{2}{*}{ Tota } \\
\hline & 6 years old & 7 years old & 8 years old & 9 years old & 10 years old & \\
\hline Finger Sucking & 2 & 8 & 6 & 9 & 2 & 27 \\
\hline Pacifier & 1 & 7 & 14 & 7 & 3 & 32 \\
\hline Bottle & -- & 4 & 8 & 3 & 3 & 18 \\
\hline Lip sucking & 1 & 2 & -- & 1 & -- & 4 \\
\hline Total & 4 & 21 & 28 & 20 & 8 & 81 \\
\hline
\end{tabular}

Table 4 - Relation between the different biting habits and age.

\begin{tabular}{|c|c|c|c|c|c|c|}
\hline \multirow{2}{*}{ Biting habits } & \multicolumn{5}{|c|}{ AGE } & \multirow{2}{*}{ Total } \\
\hline & 6 years old & 7 years old & 8 years old & 9 years old & 10 years old & \\
\hline Nailbiting & 1 & 2 & 13 & 11 & 3 & 30 \\
\hline Lip biting & -- & 2 & 2 & -- & 1 & 5 \\
\hline Biting shirt collar & 1 & 2 & -- & 3 & -- & 6 \\
\hline Biting Pen/pencil & 1 & 5 & 9 & 6 & 1 & 22 \\
\hline Biting objects & -- & -- & -- & 1 & -- & 1 \\
\hline Bruxism & -- & -- & 1 & 2 & -- & 3 \\
\hline Total & 3 & 11 & 25 & 23 & 5 & 67 \\
\hline
\end{tabular}

Table 5 - Relation between Angle malocclusion and age.

\begin{tabular}{|c|c|c|c|c|c|c|c|}
\hline \multirow{2}{*}{$\begin{array}{l}\text { Malocclusion according to } \\
\text { Angle classification }\end{array}$} & \multicolumn{5}{|c|}{ AGE } & \multicolumn{2}{|c|}{ Total } \\
\hline & 6 years old & 7 years old & 8 years old & 9 years old & 10 years old & $n$ & $\%$ \\
\hline Class I & 11 & 28 & 40 & 30 & 7 & 116 & 82.9 \\
\hline Class II & 1 & 2 & 6 & 6 & 2 & 17 & 12.1 \\
\hline Class III & 1 & 3 & 1 & 1 & 1 & 7 & 5 \\
\hline Total & 13 & 33 & 47 & 37 & 10 & 140 & 100 \\
\hline
\end{tabular}

\section{DISCUSSION}

On Table 1 it can observed that $29.2 \%$ of the sample showed an association between two or more habits, $37.9 \%$ had only one habit and in $32.9 \%$ the presence of habits was not found. These results do not match with the ones found by Soncini and Dornelles ${ }^{25}$ which showed that $49.0 \%$ of children had $2-5$ associated habits, $46.0 \%$ had only one habit and $2.5 \%$ never presented any habit. From the 140 analyzed files, it was observed that 94 patients $(67.1 \%)$ had a history of oral habits compared with $46(32.9 \%)$ of those who never presented any (Table 1). These findings are supported by literature that includes these habits as one of the etiological factors of dental malocclusion..$^{10,11,14}$ 
Table 6 - Presence and absence of habits related to malocclusion, according to Angle classification.

\begin{tabular}{|c|c|c|c|c|c|c|}
\hline \multirow{2}{*}{$\begin{array}{l}\text { Malocclusion } \\
\text { according to Angle } \\
\text { classification }\end{array}$} & \multicolumn{6}{|c|}{ Habits } \\
\hline & $\mathbf{n}$ & $\%$ & $\mathbf{n}$ & $\%$ & $\mathbf{n}$ & $\%$ \\
\hline Class I & 75 & 64.6 & 41 & 35.4 & 116 & 100 \\
\hline Class II, division 1 & 12 & 70.6 & 3 & 17.6 & 15 & 88.2 \\
\hline Class II, division 2 & 2 & 11.8 & -- & -- & 2 & 11.8 \\
\hline Class III & 5 & 71.4 & 2 & 28.6 & 7 & 100 \\
\hline Total & & & & & & \\
\hline
\end{tabular}

$\mathrm{gl}=2 ; \mathrm{a}=5 \% ; \mathrm{x}^{2}$ tabulated $=5.99 ; \mathrm{x}^{2}$ calculated $=2.18$

Organizing in decreasing order of prevalence the types of habits presented by 94 individuals in this study, was as follows: Sucking habits, biting habits, associated sucking and biting habits, habit of biting and face support (Table 2). This result is in agreement with those obtained by Soncini and Dornelles ${ }^{25}$ and Milk-Cavalcante et $\mathrm{al}^{15}$ that identified a higher prevalence of sucking habits in their samples.

On the other hand, the percentage of patients with sucking habits found here $(57.9 \%$ - 81 out of 140$)$ (Table 3) also differ from that observed for Milk-Cavalcante et $\mathrm{al}^{15}$ (70\% to $\left.77.4 \%\right)$. It is likely that this difference occurs due to variations in age of the samples studied. The sample group consisted of patients with ages from 6 years to 10 years and 11 months, whereas studies from Soncini and Dornelles ${ }^{25}$ contemplated children between 4 years to 4 years and 11 months and the study developed by Milk-Cavalcante et $\mathrm{al}^{15}$ was conducted in children between 3 and 5 .

Whereas the information gathered here was obtained by questionnaire with those responsible for the patients treated at the Clinic of Preventive Orthodontics during the clinical examination, it is possible that the time elapsed since the tender age until the time of registering the information will also contribute to the differences found between the three works mentioned.

In this study, the data were collected from the inactive file of the School of Dentistry of Ribeirão Preto - USP. For this reason, the researchers were restricted to the content of medical records. Thus, possible distortions that may possibly be presented must be considered. Perhaps the highest rate of absence of habits found in this study, when compared to the study of Soncini and Dornelles ${ }^{25}$ occurred by omission of information by parents or guardians during anamnesis. Even those patients who quit the oral habit before the time of the appointment, may not have been properly identified. The fact that there are many associated habits with the sample prevented the analysis of their effects in isolation, which is performed after the habits found were divided into sucking and biting habits.

In Table 3 we observed that the pacifier sucking habit occurred most (32), followed by sucking (27), which corroborates with the studies by Paunio et al, ${ }^{21}$ Katz et al, ${ }^{12}$ Milk-Cavalcante et al, ${ }^{15}$ Duncan et al. ${ }^{8}$

Among the different kinds of biting habits, the most prevalent was nailbiting (30), followed by pen/pencil (22) biting (Table 4), the age groups that were more involved with these conditions were 8 and 9 years old. However, Souza et $\mathrm{al}^{26}$ found a higher prevalence of object biting over nailbiting. Perhaps the limited literature on this topic is due to the fact that this kind of habit has little impact on changes in dental occlusion and is rarely described separately.

For the frequency of different types of malocclusion found by Angle, ${ }^{2}$ in this study it was observed that from all the evaluated files, most individuals showed Angle Class I (82.9\%), and most children was aged 8 years old, followed by 9 and 7 years respectively. Most of Class II (12.1\%) was found between the ages of 8 and 9, and Class III (5\%) at the age of 7 (Table 5).

The largest number of Class I patients (82.9\%), followed by Class II (12.1\%) and Class III (5\%) found in this study (Table 5), is in agreement with the work of Silva Filho et $\mathrm{al}^{23}$ and Martin et $\mathrm{al}^{17}$ and disagree with those by Vieira and Pillon ${ }^{29}$ and Singh et $\mathrm{al}^{24}$ who found in their studies, prevalence of Angle Class II malocclusion followed by Class I and Class III. 
The chi-square test was applied to verify whether individuals with oral habits presented predominance of Class II malocclusion, compared to those with no habits (Table 6). The significance level was 5\%, with 2 degrees of independence. After analysis it was found that the chi-square value calculated, obtained from data on referred table, was 2.18. Because this value is lower than the tabulated value (5.99), it was found that the null hypothesis cannot be discarded. In the research conducted in this work, it is possible to confirm this hypothesis, since the most frequent malocclusion associated with oral habits was Class II (82.4\% - 14 of 17), followed by Class III malocclusion (71.4\% - 5 of 7) and Class I (64.6\% - 75 of 116), respectively. The prevalence of Class II malocclusion probably occurs due to the fact that the Class II, division 1 patients, present in- cisor protrusion with considerable overjet, which itself facilitates the installation and maintenance of lip sucking habit and infantile swallowing.

According to the data found here, there seems to be a relation between oral habits and malocclusion, since in the three types of malocclusion defined by Angle ${ }^{2}$, the presence of habits was over $60 \%$ (Table 6).

\section{CONCLUSION}

According to the applied methodology and the conditions established in this study, we concluded:

»Deleterious oral habits are directly linked to the presence of the three types of malocclusion defined by Angle.

» A predominance of Class II malocclusion was found in patients with oral habits. 


\section{REFERENCES}

1. Agurto PV, Diaz RM, Cadiz OD, Bobenrieth FK. Frecuencia de malos hábitos orales y su asociación con el desarrollo de anomalías dentomaxilares en niños de 3 a 6 años del área Oriente de Santiago. Rev Chil Pediatr. 1999;70(6):470-82.

2. Angle EH. Classification of malocclusion. Dent Cosmos. 1899;41(3):248-64.

3. Antonini A, Marinelli A, Baroni G, Franchi L, Defraia E. Class II malocclusion with maxillary protrusion from the deciduous through the mixed dentition: a longitudinal study. Angle Orthod. 2005;75(6):980-6.

4. Bosnjak A, Vućićević-Boras V, Miletić I, Bozić D, Vukelja M. Incidence of oral habits in children with mixed dentition. J Oral Rehabil. 2002;29:902-5.

5. Caglar E, Larsson E, Andersson EM, Hauge MS, Ogaard B, Bishara S, et al. Feeding, artificial sucking habits, and malocclusions in 3-year-old girls in different regions of the world. J Dent Child. 2005;72(1):25-30.

6. Charchut SW, Allred EN, Needleman HL. The effects of infant feeding patterns on the occlusion of the primary dentition. J Dent Child. 2003;70(3):197-203.

7. Chevitarese AB, Valle D, Moreira TC. Prevalence of malocclusion in 4-6 year old Brazilian children. J Clin Pediatr Dent. 2002;27(1):81-5.

8. Duncan K, McNamara C, Ireland AJ, Sandy JR. Sucking habits in childhood and the effects on the primary dentition: findings of the Avon longitudinal study of pregnancy and childhood. Int J Paediatr Dent. 2008;18(3):178-88.

9. Felicio CM, Ferreira-Jeronymo RR, Ferriolli BHVM, Freitas RLRG. Análise da associação entre sucção, condições miofuncionais orais e fala. Pró-fono Rev Atual Cient. 2003;15(1):31-40

10. Góis EGO, Ribeiro-Junior HC, Vale NPP, Paiva SM, Serra-Negra JMC, Ramos-Jorge $\mathrm{ML}$, et al. Influence of nonnutritive sucking habits, breathing pattern and adenoid size on development of malocclusion. Angle Orthod. 2008;78(4):647-54.

11. Josell SD. Habits affecting dental and maxillofacial growth and development. Dent Clin North Am. 1995;39(4):851-60.

12. Katz CRT, Rosenblatt A, Gondim PPC. Nonnutritive sucking habits in Brazilian children: effects on deciduous dentition and relationship with facial morphology. Am J Orthod Dentofacial Orthop. 2004;126(1):53-7.

13. Larsson E. Dummy and finger sucking habits with special attention to their significance for facial growth and occlusion. 7. The effect of earlier dummy and finger sucking in 16-year-old children, compared with children without earlier sucking habits. Swed Dent J. 1978;2(1):23-33.

14. Larsson E. Prevalence of crossbite among children with prolonged dummy- and finger-sucking habit. Swed Dent J. 1983;7(3):115-9.

15. Leite-Cavalcanti A, Medeiros-Bezerra PK, Moura C. Breast-feeding, bottle-feeding sucking habits and malocclusion in Brazilian preschool children. Rev Salud Publica. 2007:9(2):194-204.
16. Levine RS. Briefing paper: oral aspects of dummy and digit sucking. Br Dent J. 1999;186(3):108.

17. Martins JCR, Sinimbu CMB, Dinelli TCS, Martins LP, Raveli DB. Prevalência de má oclusão em pré-escolares de Araraquara: relação da dentição decídua com hábitos e nível sócio econômico. Rev Dent Press Ortod Ortop Facial. 1998;3(6):35-43.

18. Morley KR, Mcintyre T. Management of non-nutritive or digit-sucking habits in children: a practical approach. J Can Dent Assoc. 1994;60(11):969-71.

19. Nanda RS, Khan I, Anand R. Effect of oral habits on the occlusion in preschool children. ASDC J Dent Child. 1972;39(6):449-52.

20. Ogaard B, Larsson E, Lindsten R. The effect of sucking habits, cohort, sex, intercanine arch widths, and breast or bottle feeding on posterior crossbite in Norwegian and Swedish 3-year-old children. Am J Orthod Dentofacial Orthop. 1994;106(2):161-6.

21. Paunio P, Rautava P, Sillanpää M. The Finnish family competence study: the effects of living conditions on sucking habits in 3-year-old Finnish children and the association between these habits and dental occlusion. Acta Odontol Scand. 1993;51(1):23-9.

22. Pereira ERBN, Trezza EMC. Identificação das atitudes dos pais e familiares frente ao uso da chupeta. J Bras Fonoaudiol. 2005;5(23):381-6.

23. Silva Filho OG, Freitas SF, Cavassan AO. Prevalência de oclusão normal e maloclusão em pré-escolares da cidade de Bauru (SP). Parte I: relação sagital. Rev Odontol Univ São Paulo. 1990;4(2):130-7.

24. Singh SP, Utreja A, Chawla HS. Distribution of malocclusion types among thumb suckers seeking orthodontic treatment. J Indian Soc Pedod Prev Dent. 2008;26 Suppl 3:S114-7.

25. Soncini F, Dornelles $\mathrm{S}$. Ocorrência de hábitos orais nocivos em crianças com 4 anos de idade, de creches públicas no município de Porto Alegre (RS), Brasil. Pró-fono. 2000;12(2):103-8

26. Sousa FRN, Taveira GS, Almeida RVD, Padilha WWN. O aleitamento materno e sua relação com hábitos deletérios e maloclusão dentária. Pesq Bras Odontopediatria Clín Integr. 2004;4(3):211-6.

27. Tausche E, Luck O, Harzer W. Prevalence of malocclusions in the early mixed dentition and orthodontic treatment need. Eur J Orthod. 2004;26:237-44.

28. Tomita NE, Bijella VT, Franco LJ. Relação entre hábitos bucais e má oclusão em préescolares. Rev Saúde Pública. 2000;34(3):299-303.

29. Pillon J, Vieira MM. Freqüência da ocorrência de maloclusão dentária em crianças com hábitos orais deletérios. Fono Atual. 2001;4(17):23-31.

30. Viggiano D, Fasano D, Monaco G, Strohmenger L. Breast feeding, bottle feeding, and non-nutritive sucking; effects on occlusion in deciduous dentition. Arch Dis Child. 2004;89(12):1121-3. 